\title{
Preparations of LNG Bunkering Facilities in the United States
}

\author{
Khairul Ahmad ${ }^{a}$ and Pengfei Zhang ${ }^{b *}$ \\ ${ }^{a}$ Southampton Solent University \\ ${ }^{b}$ Dalian Maritime University, China
}

*Corresponding author: Pengfei Zhang, Dalian Maritime University, China.

Highlights of this Article

a. LNG as the alternative energy that can substitute crude oils to reduce carbon emissions.

b. Characteristics of LNG that are greener, flexible and cheaper compared to conventional fuels.

c. The market demand of LNG globally and in the United States that concludes the trends of modifications for LNG bunkering facilities in Northern America.

d. Regulations required by United States LNG bunkering facilities to operate the safest and efficient LNG transferring procedures.

\section{Abstract}

Following the good news of the Liquefied Natural Gas (LNG) market booming, the United States (US) is preparing its best to be the major and effective LNG supplier. Due to this demand, the LNG market is appealing not only to the US but to Australia as well since the country is also one of the largest LNG producers in the world [1]. According to the US Energy Information Administration (EIA), the demand has been growing globally as natural gas will become the gas of alternative energy. To fulfill this demand, the US economic interest becomes targeted on the Liquefied Natural Gas (LNG) import terminals installation specifically in the country's northern region. In viewing the growing LNG market, LNG bunkering facilities in Northern America are preparing expenses to modify their terminals in smoothing the LNG transferring process. Thus, this paper explores the preparations of LNG bunkers in Northern America with some LNG facilities that are included to show the preparations of the US in becoming the major exporter of LNG globally.

Keywords: Liquefied natural gas (LNG); Bunkering; Facilities; United states

\section{Introduction}

In recent years, the energy demand has been satisfied largely by the consumption of fossil fuels like petroleum, natural gas and coal. These fossil fuels have coated the $87 \%$ of US energy demand during the last decade [2]. During the last century, the US has exported natural gas via pipeline to Canada and Mexico. The quantity of natural gas exported has been less than imported. The only LNG export terminal of domestic production that has been operating since 1969 is the Kenai LNG Plant situated in Alaska which still in use for exporting LNG primarily to Japan. By 2000, the US was committed to a consolidation method of supply the natural gas demand by importing LNG. Forecasting reports given in 1999 by the Energy Information Administration (EIA) stated that natural gas imports were progressing to growth from $12.9 \%$ to $15.5 \%$ from 1997 to 2020 [3]. Based on these reports, five new LNG import terminals were designed, and some other existing facilities went through growth modifications. However, the mass production of natural gas throughout the last decade has changed the economic interests of the American business. The natural gas surplus has been encouraged by the progress on drilling technologies like "fracking", which have simplified the extraction method of this natural resource. As the result of the fast growth of domestic natural gas production, most of the prevailing import facilities became unproductive. According to the most recent forecast studies performed by the EIA, the US will be positioned in the third position of the largest liquefaction capacity by 2020 after Australia and Qatar [3]. Around 50 permit applications for the development of recent LNG export terminals, or for the modification of existing import terminals are received in January 2015. Four of the applications are approved 
and some already under construction which is aligned to integrate liquefaction facilities to the already existing import terminals, which are better-known as brownfield projects. Brownfield refers to land within the United States that was used before for an industrial or commercial purpose and potentially contains dangerous waste or pollution in the current times [4].

\section{Methods}

The research approach conducted in this thesis will work as a framework to analyse the preparations of LNG bunkering facilities in Northern American. Broadly, this dissertation will focus on three investigation areas where the first area of focus will be the quantitative aspect of LNG market by globally and in the US. While the second area will be using qualitative to see the planned facilities in US LNG bunkering and the regulations required to be followed by the facilities' operators. Furthermore, quantitative researchers highlight the analysis and measurement of causal relationships between variables, not processes. The derived result of the quantitative analysis will provide an objective conclusion whether the source of natural gas in US may be viable or not in an economic sense. The result of using qualitative analysis is to examine the development planned by US government to expand the growth of US LNG bunkering from its facilities perspectives. In contrast to the investment made by well-known companies as stated in Chapter 4 , this research will show some explanations for each project as it describes the procedures and expected productions of LNG. The information was collected from web sources about LNG facilities in Northern America for examples ABS, USCG and EIA. These web sources are the most used sites for the maritime industry in the US that provide important and knowledgeable information. EIA includes both qualitative and quantitative data and is used mainly in both descriptive and explanatory research [5] for the LNG market in the US. While ABS, the website provides qualitative data where it shows the research and projects of LNG bunkering facilities in Northern America. The qualitative data also retrieved from USCG where the web source prepared the regulations for the operators at LNG bunkering facilities. The limitations of this research are the study is only focused on LNG bunkering operations from storage stranded and vehicle fueling perspective but not including other facilities for the development of LNG bunker in Northern America. Moreover, analysis collected only covers infrastructure required of LNG bunker facility in Northern America and does not include any necessary infrastructure of LNG bunker facility in the whole United States.

\section{LNG Characteristics and the Market Analysis}

\section{Characteristics of LNG}

LNG is a natural gas that has been cooled to the point that it combines to be fluid, which happens at a temperature of approximately $-162^{\circ} \mathrm{C}$ (Celsius) in atmospheric pressure. Natural gas is transformed into liquid form through liquefaction procedure to empower transportation over long distances particularly, where the distribution pipelines are most certainly not viable or different limitations exist. When petroleum gas is changed over to LNG, the volume is diminished by a factor of 610 and it allows transportation and storage in huge volumes [6] (Figure 1).

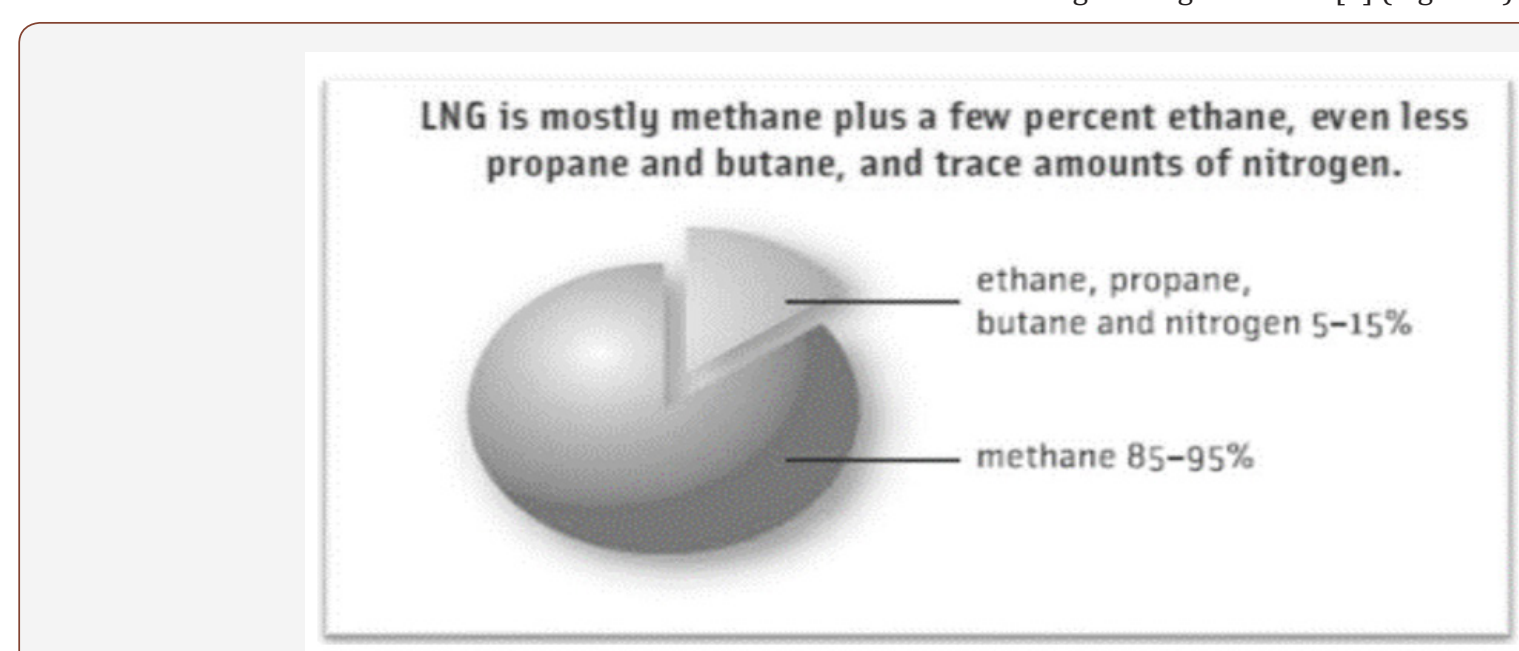

Figure 1: Natural Gas Components [49].

Natural gas is a blend of different hydrocarbon gas known in scientific names for examples propane, methane, butane and ethane. Based on Figure 1 above, more than $80 \%$ of natural gas is shaped by methane which is the main element. To increase as much as the use, natural gas must be extracted. The particles can be separated from the gas via the natural gas processes at the gas partition plants. Each of the particles has a broad variety of uses [7]. With every other particle that exists, LNG has characteristics that make it special. These characteristics also relying on its area or region. The usual characteristics for LNG are:

1. Colorless;

2. Odorless;

3. Non-toxic but can cause asphyxiation in unventilated areas; 
4. Non-corrosive cryogenic liquid at atmospheric conditions;

5. The density is in the range of $430-470 \mathrm{~kg} / \mathrm{m}^{3}$ (Kilogram per Cubic Meter), depending on its composition;

6. LNG is normally kept at the atmospheric pressure less than 5 PSI gauge and

7. It has a boiling point of $-162^{\circ} \mathrm{C}$

(Source: Mokhatab et al. [18]).

\section{LNG prices}

The supply chain and reserve of LNG make the cost competitive [9]. In Europe, the supply of gas by pipeline gives more competitive costs compared with imports by vessels while the LNG supply facilities are ending up more liberalized (IMO 2016). Fuel costs is a factor that can radically influence the LNG prices [10]. Fuel costs is an unstable market, and the difference in prices has a huge effect on profits that are made by bunkering firms. This will decide the payback time for the investments made by the bunkering organizations [11]. Currently, there is no regular international pricing tools for natural gas and as a result, regional gas prices differ globally as shown in Figure 2 below. However, there are tools that are utilized to provide competitive market, regulated and oillinked pricing. Oil-linked pricing connects natural gas in trading to long-term oil prices with the regulated prices established by governments and specific discount. While for the competitive pricing, it provides trading points to be used by consumers and suppliers to decide the value [12] (Figure 2).

Figure 2: Estimated landed prices of LNG worldwide as of May 2017 [48].

Based on Figure 2 above, the utilization of different price mechanisms globally produces problems and conducts to improving international trade to use arbitrage opportunities. This forces on suppliers and customers to adjust their costs with traded markets. Even though there is vulnerability to the future price system that will continue, both World Energy Council (WEC) and USEIA predict that the competitive natural gas market will ultimately control the market [12]. In addition, these organizations also observed that natural gas prices have separated from petroleum fuels which it might not affect the LNG price. Different areas of Europe and Northern America are focusing on progress towards competitive approach. Moreover, it is predicted that Asia also likewise to acquire the similar approach [13].

\section{LNG market in the united states}

(Figure 3)

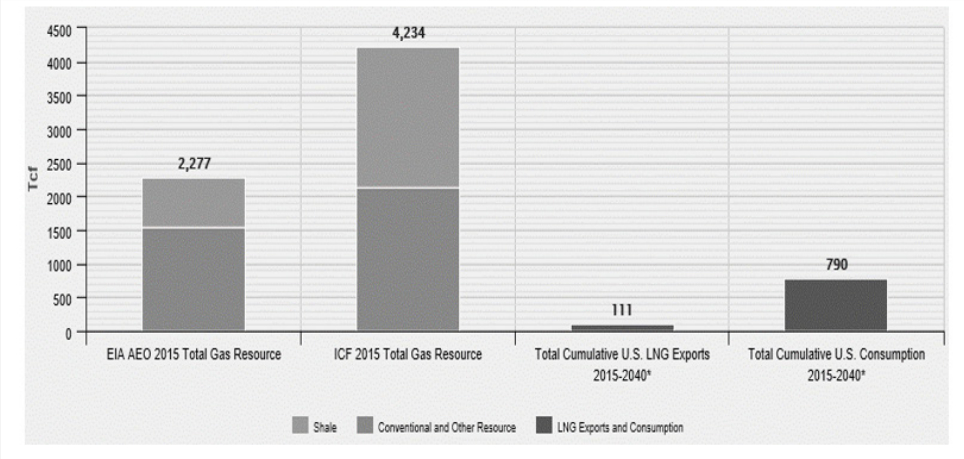

Figure 3: US Natural Gas Resources and Consumption [3]. 
Based on Figure 3 above, the USEIA estimates that the total US technically retrievable dry natural gas capacity is 2,277tcf (Trillion Cubic Feet). EIA has calculated the integrated progressive US domestic utilization and LNG exports from 2015 to 2040 indicate less than $40 \%$ of this resource. Moreover, EIA has estimated the accessible resource is stable [14]. Industry calculates that the US natural gas resources at the base are usually higher. US has sufficient natural gas to provide each local utilization and LNG exports into longer term without any problems. The ICF International estimated of $4,234 \mathrm{tcf}$ which means $85 \%$ bigger [3]. Moreover, US also provided natural gas without vulnerable by LNG export quantities are projected into EIA's Annual Energy Outlook (AEO) 2016 Reference Case Study.

\section{The benefits of the united states lng exports}

(Figure 4) Exporting natural gas creates a variety of advantages to the United States. Based on Figure 4 above, it shows that under a several of export situations, most of the growth in LNG exports are supported by increased domestic output instead of reductions in domestic demand. Growing natural gas production supports thousands of extra jobs. An IHS report predicts that for every 1 BCF/D (Billion Cubic Feet per Day) of shale gas production, the economy is supported by some 32,000 total jobs (IHS Report 2013). In addition, LNG exports may contribute the maximum amount as $\$ 10$ billion to $\$ 31$ billion per state to the economies of natural gas- producing states [15]. Moreover, non-natural gas producing states also can take the benefits in growing demand for cement, steel, equipment and other product. Generally, varied studies have found that higher levels of LNG exports can provide economic gains for the United States [14]. Exports can give advantages to the US in the manufacturing sector. Expanding in natural gas production brings up in LNG that can be used as organic petrochemical feedstocks. ICF International analysed the effects of LNG exports and found out that NGL volumes will increase between 138,000 and 555,000 BPD (Barrels Per Day) by 2035 [3]. According to ICF, an expanding in LNG supply will provide in preserving the reasonable LNG prices and this edges the domestic manufacturing industries [16]. US LNG exports also provide a reliable and alternative energy supply to the world marketplace, offering international buyers with a better alternative or an option, serving to limit the utilization of energy as a political weapon. Environmentally, US energy-related carbon dioxide emissions in 2015 were 12\% below 2005 levels due to high utilization of natural gas by power generators. In addition, exporting LNG can decrease the global greenhouse gas emissions (GHG) [17]. ICF predicts that exported LNG can have GHG emissions in between of $43 \%$ to $52 \%$ which is much lower than the emissions of traditional oils. Moreover, Energy Department concludes that US's natural gas used in Asia or Europe has lower life cycle of GHG emissions compared to the power generates by regional coal [14] (Figure 5).

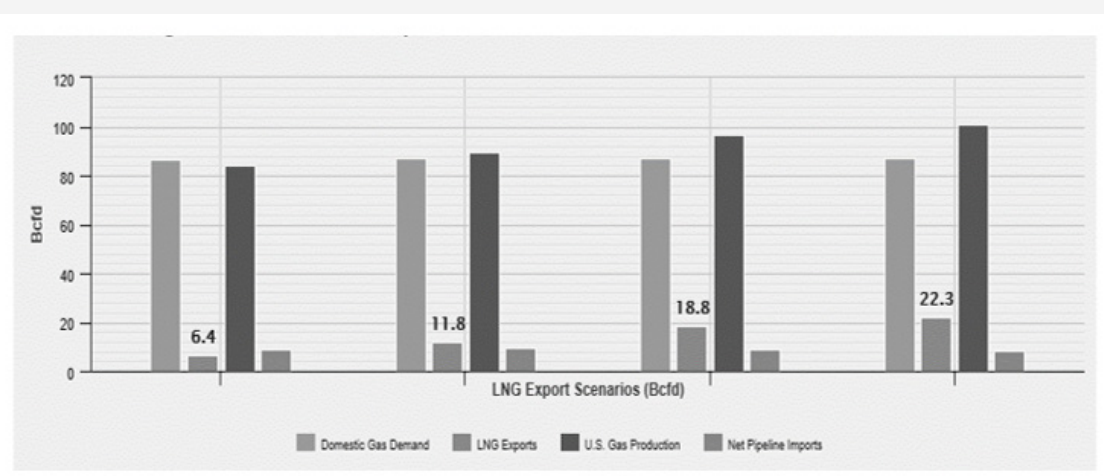

Figure 4: Projected US Domestic Demand, Production, Net Pipeline Imports and Levels of LNG Exports [3].

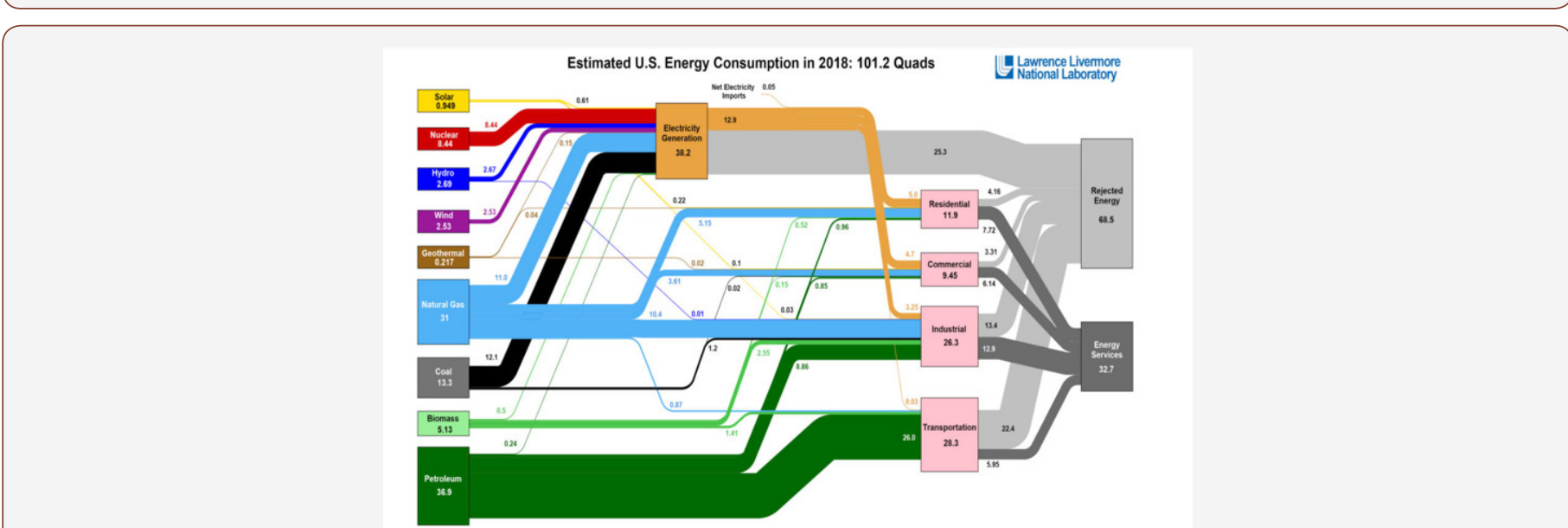

Figure 5: Estimated U.S. Energy Consumption in 2018 [46]. 
Based on Figure above, natural gas supply grew from 28 in 2017 to 31 in 2018 which the exact natural gas consumption in US is 3 quadrillion BTU. This reflects a significant growth for gas to replace coal for electricity generation. As for examples, 2018 faced hotter summer compared in 2017, where electricity for air conditioning was required and driven the gas utilization to a high demand. In addition, US also had a colder winter, which gas demand had been increased for warming the residential areas.

\section{Future Planning of LNG Bunkering Facilities in the Northern America}

\section{Introduction}

As stated in chapter 3 , the LNG market is encouraging the United States to gain a lot of profit. Thus, in this chapter, the proposed of LNG bunkering facilities are explained by providing examples of planned projects that represent one type of planned bunkering facility (On-site/Plants Liquefaction), based on the process in receiving, storing and refueling of LNG. Other than that, utilization of trucks for a type of transferring situations also is explained (Truck Transportation to Vessel Bunkering). Moreover, future projects with well-known companies also are described in this chapter to illustrate the aspects of LNG infrastructure which are predicted to be satisfied and to achieve the second objective. This chapter is explaining the second objective as stated in Chapter 1.

\section{Overview of us lng infrastructure}

The LNG infrastructure consists of interconnected facilities that cover the method and transportation of natural gas from the well to the final client. Every plant, equipment, and transportation modes involve specific challenges associated with the specific physical characteristics of the dangerous materials related to the various stages on the LNG value chain [17]. Based on Figure 5 below, it shows the proposed and ongoing LNG bunkering project locations in the US. From the figure, it is shown that US is preparing a lot of LNG bunkering projects to have the biggest capacity of LNG (Figure 6).

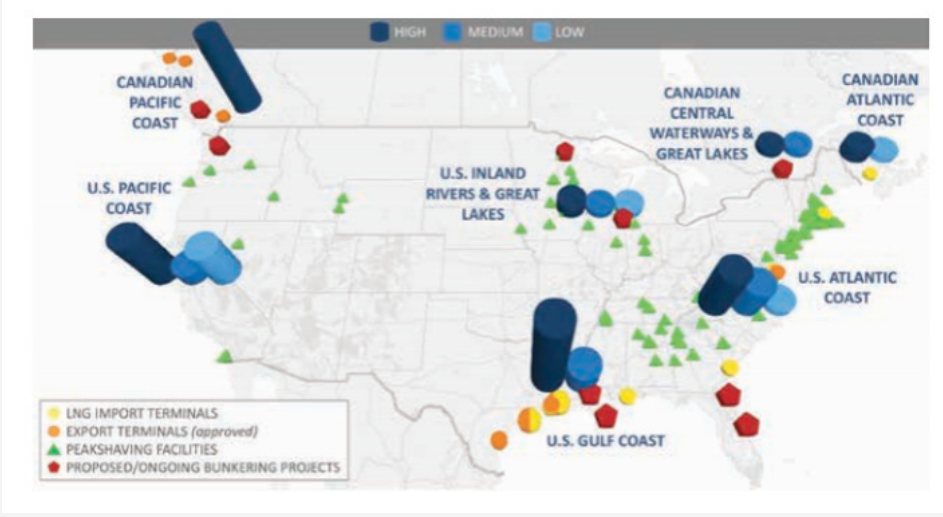

Figure 6: Potential LNG Sources and Ongoing Bunkering Project Locations [31].

\section{Stranded storage (on-site/plants liquefaction)}

On top of the facilities listed in this chapter, bunkering facilities with an on-site liquefaction solution typically need more investment in terms of equipment and land. It will additionally give the biggest production and capacity. Plants or Onsite can be designed for a high efficiency with relevant processes by investing some additional cost. Although, it is more essential to make the plant easy to operate. The focus is to have an optimal balance between operational flexibility, cost and energy efficiency that produces the best return on investment [18]. Nowadays, liquefaction plant supplies LNG to LNG fuelling stations by trucks that are intentionally designed to distribute cryogenic fuels. At the fuelling site, LNG is unloaded into the facility's storage tank. Mostly at LNG stations, the LNG moves through a pump to an ambient air vaporizer that functions to swap the heat. In this vaporizer, the temperature of the LNG is exaggerated to roughly $-200^{\circ} \mathrm{F}$ (Fahrenheit). The pressure conjointly will increase but the fuel stays as a liquid. This method is named "conditioning" [19] (Figure 7).
Based on Figure 6 below, it shows the process of LNG transferring. After conditioning, LNG is kept in giant cryogenic storage tanks either underground or above. These storage tanks are often configured vertically or horizontally and are generally found in capacities of 15,000 or 30,000 gallons. When needed, LNG is distributed as a liquid into cryogenic tanks on-board the trucks. Unlike conventional fuelling stations, LNG stations must address various functionality requirements and unique design, fuel conditioning, including tank truck offloading, vapor management and venting minimization, cryogenic fluid storage and processing, codes and standards compliance, and special metering and dispensing challenges [19].

\section{Harvey gulf port fourchon, Louisiana:}

(Figure 8)

Harvey Gulf has built a bunkering facility at Port Fourchon, Louisiana (Refer to Figure 7 above) to assist Offshore Provide Vessels (OSVs). Harvey Gulf has invested around \$25 million for the 
LNG supplying facility at Port Fourchon, Louisiana [20]. The Port Fourchon facility contains vacuum-insulated LNG storage tanks and double-walled that follow the American Society of Mechanical Engineers (ASME) Boiler and Pressure Vessel Code requirements. For LNG storage at vehicle fuelling stations, the appropriate requirements for storage tanks are explained in chapter 6. According to the requirements, the storage tanks can fill in about 100,000 gallons $(378,000$ Litre) capacities or less, with most combination storage capacity at a single fuelling facility of 280,000 gallons (1060 $\mathrm{m}^{3}$ ). In addition, NFPA 59A additionally provides requirements for such tanks. This development can include two facilities, each having 270,000 gallons $\left(1022 \mathrm{~m}^{3}\right)$ of LNG storage capacity. Initial plans require the facility storage tanks to be filled with LNG and delivered to the facility by trucks, although transfer to and from barges is planned in later phases of the project [21]. Apart from the first role of supply vessels that assist the oil and gas business, the facility also can assist over-the-road vehicles that operate on LNG.

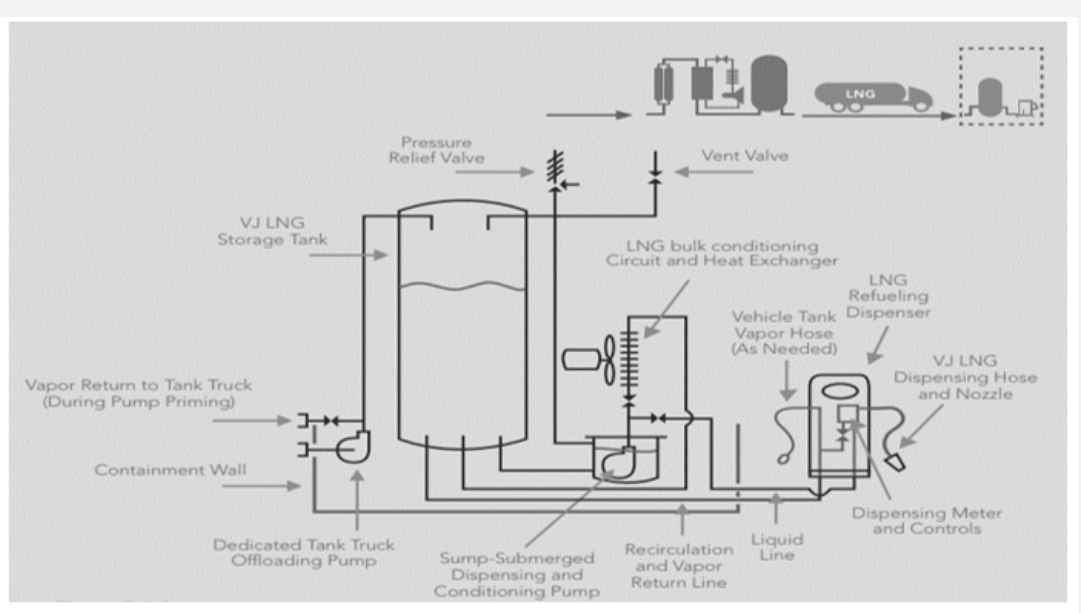

Figure 7: Liquefier Located Onsite at LNG Fuelling Station [19].

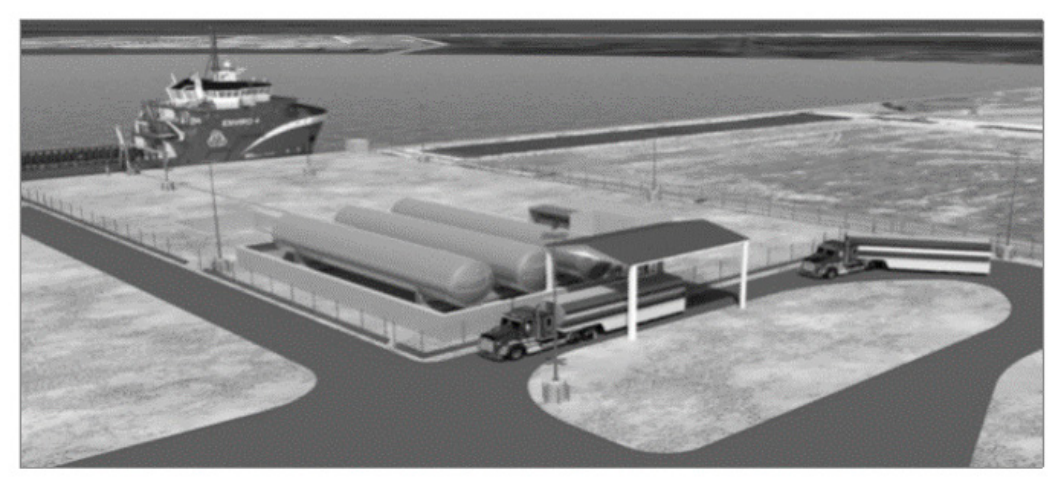

Figure 8: Harvey Gulf International Marine's LNG facility at Port Fourchon, LA [31].

Shell Ing bunkering facilities in geismar, louisiana: In 2013, Shell plans to bring LNG fuel to its heavy-duty on-road and marine consumers in North America by developing two small-scale liquefaction units. These two units creates the utilization of two new LNG transport in the Gulf Coast and Great Lakes regions [22]. This result followed by an investment decision in 2011 on the same passageway in Alberta, Canada [23]. In 2013, Shell specified that the facilities would take three years to be operated. Each liquefaction plant has a specific capacity of 250-million kilograms $(250,000$ tonnes) of LNG per annum. In the Gulf Coast corridor, Shell plans to put in a liquefaction plan at the Shell Geismar Chemicals facility in Louisiana. When the liquefaction plan is operating, this unit can provide LNG along the Mississippi River, the offshore Gulf of Mexico, the Intra-Coastal Waterway, and the onshore oil and gas exploration areas of Louisiana and Texas [24]. Shell features a memorandum of understanding with Edison Chouest Offshore companies to allow LNG fuel ships that sail within the Gulf of Mexico and to provide LNG bunkering and barging operation in North America at Port Fourchon, Louisiana [25]. Moreover, Shell is growing LNG transport barges to deliver the fuel from the Geismar production site to Port Fourchon, where it will be transferred into client's vessels. In the Great Lakes corridor, Shell has planned to develop a liquefaction unit at Shell Sarnia Manufacturing Centre in Sarnia, Ontario, Canada. When operates, this project can supply LNG fuel to all or any five Great Lakes, Canadian provinces, the St. Lawrence Seaway and Shell's bordering US states. The Interlake steamship company is expected to be the main marine client in this area because it has started the conversion of its vessels ([26]. 


\section{Vehicular fuelling (truck transportation to vessel bunkering)}

Based on Figure 8 and 9 below, this method of bunkering is an approach where it does not need a "bunkering facility" during the vessel is bunkered at a dock with LNG transferred directly from an LNG truck. Even though there are no infrastructure associated with a facility needed, USCG regulations for bunker transferring still have to be met, and it is predicted that the local Captain of the Port (COTP) will need to analyse and approve the locations at which such transfers are planned. Nowadays, tank trucks can move about 10,000 gallons where this practice is most feasible for smaller quantities. Transportation distance from LNG storage facility, available bunkering time, dock space and other issues can make this fuelling procedure logistically challenging if more than a few trucks are needed ([27] (Figures 9,10).

Figure 9: Truck as a Facility for Transferring LNG to Vessel [42].

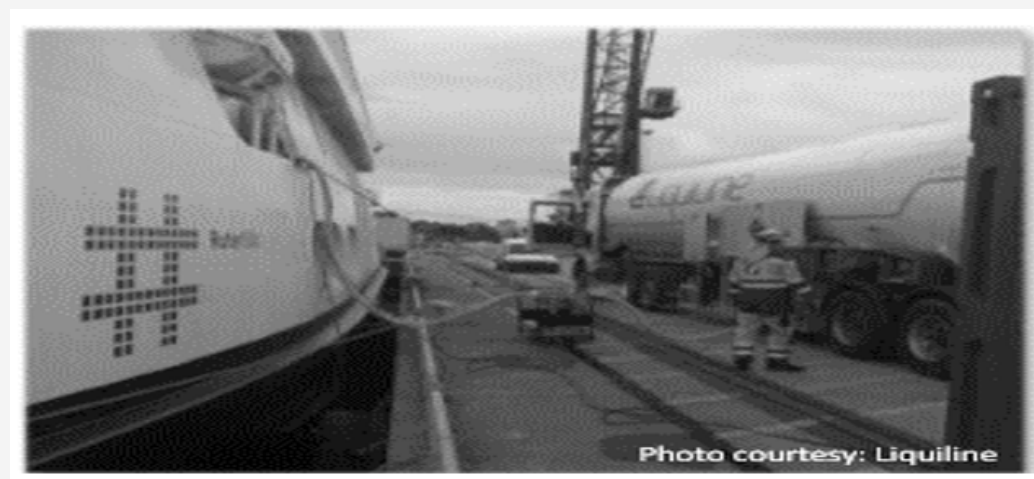

Figure 10: Truck as a Facility for Transferring LNG to Vessel [42]

Washington state ferry (wsf) lng conversions: WSF plans to convert the Issaquah, the common Ro-Ro/Passenger vessels at Washington to use LNG as fuel. The conversion will require retrofitting LNG tanks on the highest decks of vessels, located between the exhaust. The retrofit will also need installation of associated cryogenic piping. The set-up to bunker the vessels is by transferring LNG directly from trucks to the vessels. This approach can enable WSF to buy LNG at existing LNG supply locations and fuel at one or a lot of applicable dock locations wherever the vessels decision in the normal course of their operation [28].

Conversion project for staten island ferry to use lng as fuel: The project funded partly by a Maritime Administration (MARAD) permit, the New York Department of Transportation (DOT) goes to change every small ferry to receive LNG as a fuel source. The set up for the project is to choose a location at one in every of the ferry terminals (or another location if seems a much better choice) and convey an LNG truck to its dock to proceed with the LNG transferring. The plans are being coordinated with state, municipal and federal agencies as a part of an illustration project for MARAD [29].

\section{Regulations for Bunkering Facility 0perators in the Northern America}

\section{Introduction}

This chapter explains the regulations created by various organizations in the US and must be followed by the LNG bunkering facilities in Northern America. These organizations are established as guidelines for the operators at LNG bunkering facilities in the US. Thus, this chapter will cover the third objective as stated in Chapter 1. The Maritime Administration (MARAD) with the Department of Transportation (DOT) stated their mission which is "to strengthen US maritime transportations system-including labour, industry and infrastructure - to meet the security and economic needs of the Nation" [30]. Policy and guidelines for LNG bunkering always 
remain "work in progress" to make sure the current regulations are suitable [31]. Current federal regulations, codes, and standards addressing facilities handling LNG within the United States are listed in Figure 11 below (Figure 11).

In addition to the federal laws listed in Figure 11 below, there are also a few states and local regulations that bunkering facility operators must obey. Figure 11 is an easy guidance tree to help potential LNG bunkering facility operators in searching which of the present federal laws, standards and codes may be appropriate to their site based on (1) how LNG is being transferred to the facility and (2) whether the facility has an onsite bulk storage tank or not. The answers to these two questions classified a potential operation into the two bunker facilities as stated in chapter 5. Just for information, every regulation is exclusive and there are many exceptions which will affect the facility's needs [31].

(Figure 12)

\begin{tabular}{|l|l|}
\hline USCG \\
\hline - & 33 CFR 105 - Maritime Security: Facilities \\
- & 33 CFR 127 - Waterfront Facilities Handling LNG and Liquified Hazardous Gas \\
\hline Occupational Safety and Health Administration (OSHA) \\
\hline - 29 CFR 19.10 .119 - Process Safety Management of Highly Hazardous Chemicals \\
\hline $\begin{array}{l}\text { Department of Transportation (DOT) Pipeline and Hazardous Materials Safety Administration } \\
\text { (PHMSA) }\end{array}$ \\
\hline - $\quad 49$ CFR 193 - LNG Facilities: Federal Safety Standards \\
\hline National Fire Protection Association (NFPA) \\
\hline - NFPA 52 - Vehicular Gaseous Fuel Systems Code \\
- NFPA 59A - Standard for the Production, Storage and Handling of LNG \\
\hline
\end{tabular}

Figure 11: US Regulations, Codes and Standards for LNG Facilities [31].

Figure 12: Bunker Facility Decision Tree [31].

\section{NFPA 59 - Stranded storage (louisiana and ontario)}

Harvey Gulf has opened its first marine LNG fuelling terminal in North America and completed a successful LNG bunkering of the ENERGY from a new constructed LNG terminal facility at operation base in Port Fourchon, Louisiana. The terminal is designed to fulfil the requirements of 33 CFR part 127 NFPA 59A and able to transfer LNG at a pumping rate of $550 \mathrm{gpm}$ (Gallons per Minute) [32]. The regulations below are also applied to Shell Bunkering Facilities in Louisiana.

\section{Chapter 7 of NFPA 59A}

The National Fire Protection Association has established NFPA 59A. Some of the requirements are shown below:

1. 7.3.1.1 - The parts of LNG containers that usually are exposed to LNG and all materials used in contact with LNG or cold LNG shall be chemically and physically suitable with LNG and intended to use at $-168^{\circ} \mathrm{C}$.
2. 7.3.1.3 - The LNG tank systems must be designed for both the bottom and top filling unless other is provided to prevent combination of other materials.

3. 7.3.1.5 - Where two or more tank systems are situated, each tank system foundation must be able for resisting any exposure to LNG or shall be secured from contact to LNG that might damage the structure.

4. 7.3.1.6 - The density of the liquid shall be presumed to be the actual mass per unit volume at the minimum storage temperatures [33].

\section{NFPA 52}

The NFPA code applies to the operation maintenance, installation and design of LNG engine fuel systems on vehicles of all types, as well as to associated fuelling facilities. It also applies to LNG to CNG facilities with LNG storage in ASME containers of 70,000 gallons or less [34]. These regulations can be applied to trucks which are transporting LNG to vessels as stated in Chapter 5. 


\section{Vehicular gaseous fuel systems code}

The NFPA 52 applies to the operation, installation, maintenance and design of LNG engine fuel systems and Compressed Natural Gas (CNG) on vehicles of all types and for associated storage and fuelling vehicle systems, including the assisting marine ships [35]. It addresses:

1. Original equipment manufacturers

2. Vehicle fuelling (dispensing) systems

3. Final-stage vehicle manufacturer/integrator

[35] It applies to the operation, installation, maintenance and design of LNG engine fuel systems on vehicles of all types, to connected fuelling facilities and to LNG storage in ASME containers of 70,000 gallons $\left(265 \mathrm{~m}^{3}\right)$ or less. Even though there is no enlightenment on LNG, NFPA 52 may be the suitable standard for an LNG bunkering facility to use in reaching the requirements in local and state laws that contain provisions that need facilities to fulfil the standards and codes and suitable to the facility [35].

\section{USCG Regulations}

Other than focusing on the trucks and storage tanks, USCG also has established a regulation about the safety of the LNG bunkering terminals including its facilities. This can be applied to the planned projects of LNG bunkering in Northern American region.

33 CFR 105 Maritime security: facilities: LNG bunkering terminals are going to be subject to the Maritime Transportation Security Act (MTSA) regulations under 33 CFR half 105 - Maritime Security: Facilities. This regulation needs enlarge a Facility Security Plan (FSP), an operator to perform a Facility Security Assessment (FSA) and submit the FSP to the USCG for approval before operation of the terminal [36]. The safety requirements that must be addressed include:

1. Defining security organizational structure.

2. Designating a Facility Security Officer (FSO).

3. Performing a security assessment.

4. Developing and submitting an FSP.

5. Ensuring Transportation Worker Identification Credentials (TWIC) are properly implemented.

6. Ensuring restricted areas are controlled.

7. Ensuring adequate security coordination between the facility and vessels that call on it.

8. Ensuring timely implementation of additional security measures for increased Maritime Security (MARSEC) levels.

9. Ensuring security for unattended vessels.

10. Ensuring reporting of all security breaches.
11. Ensuring consistency between security and safety requirements.

12. Informing all facility personnel on their TWIC responsibilities.

[36] Since LNG is considered as a Certain Dangerous Cargo (CDC) by the USCG, the extra security is needed which should be addressed in furthering the protection of the facility, together with an escort of visitors, vehicle restrictions and redoubled finding of waterfront areas. The FSA needs a set of background information which is the completion of an onsite security survey of existing protective procedures, analysis, operations and measures of the information to suggest security measures for additional to the FSP [36].

\section{Additional regulations for lng bunkering operators}

Other than regulations explained above, there also a few regulations that were established Code of Federal Regulations (CFR) and Occupational Safety and Health Administration (OSHA). These organizations also contributing significantly due to the expanding in development of LNG bunkering terminals in Northern America.

Waterfront facilities handling lng and liquefied hazardous gas - 33 CFR 127: 33 CFR Part 127 established a regulation for waterfront facilities handling LNG written to deal with the LNG export or import as cargo. The regulation also contains rules for LNG which being transferred by shore-based structures and vessels. These regulations are established to make sure that a maximum level of safety is used for transferring LNG operations between marine vessels and shore structures. The requirements outlined in focusing to (1) General Design (2) General Information (3) Operations (4) Maintenance (5) Equipment (6) Security and (7) Firefighting [37]. The regulations cannot expect all potential situations. Thus, provisions are included to produce facility operators with the option to manage with using procedure, methods or equipment to be used in the in the facility as written in part 127. The procedures for considering alternatives are stated in 33 CFR 127.017.

Process safety management (psm) of highly hazardous chemicals by OSHA - 29 CFR 1910.119: OSHA's Process Safety Management (PSM) regulation established requirements for minimizing or preventing the outcomes of harmful releases of toxic, flammable, reactive, or explosive chemicals. These releases may create explosion hazards or fire [38]. The regulation applies when:

1. A process which involves a chemical at or above the specified threshold quantities listed in Appendix D to the regulation

2. A process which involves flammable liquid with a flashpoint below $100^{\circ} \mathrm{F}\left(37.8^{\circ} \mathrm{C}\right)$ on site in one location, in a quantity of $10,000 \mathrm{lb}(4,536 \mathrm{~kg})$ or more. This would apply to LNG since its primary component is methane, a flammable gas. 
Thus, OSHA's PSM would apply to LNG bunkering facilities which have LNG storage tanks of more than 4,536 kg of LNG. However, if another federal agency regulates the facility for safety hazards and fire, OSHA is prohibited from regulating it under the PSM regulation [38]. The facility operator must create a PSM program if the PSM regulation applies to the bunkering facility that consists of 14 elements stated in the regulation [39]. (Figure 13)

\begin{tabular}{|l|l|}
\hline \multicolumn{2}{|c|}{14 Elements } \\
\hline$\cdot$ Employee participation & $\cdot$ Hot work permit \\
\hline • Process safety information & $\cdot$ Management of change \\
\hline • Process hazard analysis & $\cdot$ Incident investigation \\
\hline$\cdot$ Operating procedures & $\cdot$ Emergency planning and response \\
\hline • Contractors & $\cdot$ Compliance audits \\
\hline - Pre-start-up safety review & $\cdot$ Trade secrets \\
\hline - Mechanical integrity & $\cdot$ Training \\
\hline
\end{tabular}

Figure 13: 14 elements in PSM regulation [38].

\section{Conclusion}

To meet these requirements, facility operators must make sure that they document the required process safety information, use it to manage a process hazards analysis and perform a pre-start-up safety review to introduce LNG into the facility. However, there is no approval and evaluation by OSHA required for the facility's PSM program. The program compliance with the regulation would only be examined by OSHA if the agency chose to inspect after the facility was operating.

\section{Acknowledgement}

None.

\section{Conflicts of Interest}

No conflict of interest.

\section{References}

1. Rusell C (2017) Europe set to be natural gas kingmaker as LNG booms. Reuters, UK.

2. Grose T (2015) Liquid natural gas in the United States: A history. (5): 840, USA.

3. Energy Tomorrow (2017) Liquefied Natural Gas Exports: America's Opportunity and Advantage. USA.

4. Environmental Works (2018) What Is a Brownfield Project? Environmental Works.

5. Saunders MP, Lewis A, Thornhill (2016) Research Methods for Business Students. Edinburgh, England.

6. Society of International Gas Tanker and Terminal Operators (2016) Liquefied gas handling principles on ships and in terminals (LGHP4). 4th Edition. Edinburgh, England.

7. Vandebroek L, Berghmans J (2012) Safety Aspects of the use of LNG for Marine Propulsion. ScienceDirect, 45: 21-26.

8. Mokhatab S, John YM, Jaleel VV, David AW (2013) Handbook of Liquefied Natural Gas. Elsevier Science \& Technology, Boston, United States.

9. Ashworth J (2012) LNG Markets Perspective. Africa.

10. Ge J, X Wang (2016) Techno-economic study of LNG diesel power (dual fuel) ship. 16(2): 233-245.
11. Schinas O, Butler M (2016) Feasibility and commercial considerations of LNG-fueled ships. Ocean Engineering 122: 84-96.

12. (2013) Energy Information Administration (EIA). International Energy Outlook. US.

13. Lowell D, Wang H, Lutsey N (2013) Assessment of The Fuel Cycle Impact of Liquefied Natural Gas as Used in International Shipping USA.

14. Adrian CM, Kleiman S, Livermore KB, Medlock (2015) The Macroeconomic Impact of Increasing U.S. LNG Exports.

15. Potential Gas Committee (2017) Record Future Supply of Natural Gas in The U.S. Potential Gas Committee, USA.

16. IHS Report (2013) America's New Energy Future: The Unconventional Oil and Gas Revolution and The Us Economy.

17. Lixue J, Xunmin O, Linwei M, Zheng L, Weidou N (2013) Lifecycle GHG emission factors of final energy in China. Science Direct 37: 2848-2855.

18. Wärtsilä (2014) Completing the LNG Value Chain. USA.

19. TIAX (2012) U.S. and Canadian Natural Gas Vehicle Market Analysis: Liquefied Natural Gas Infrastructure. USA.

20. G Captain (2013b) Harvey Gulf to Build United States' First LNG Bunkering Facility at Port Fourchon. Louisiana.

21. Oil \& Gas Financial Journal (2016) Harvey Gulf delivers North America's first LNG marine fuelling terminal. Oil \& Gas Financial Journal, USA.

22. G Captain (2013a) Shell to Boost LNG Fuel Access in Louisiana, Ontario. USA.

23. Rudakov A (2013) Shell to build LNG plants in Ontario and Louisiana. Financial Post, USA.

24. Lng World News Staff (2013) Shell Plans LNG Fuel Plants in North America. Lng World News, USA.

25. Shell Global (2013) Shell to develop two additional natural gas for transport corridors in North America. Shell Global Media, USA.

26. Ship \& Bunker (2013) Shell in Great Lakes LNG Bunkering Deal. Ship \& Bunker.

27. Caughlan S (2010) LNG Use for Washington State Ferries. USA.

28. Workboat Staff (2013) Washington plans to convert six ferries to LNG. Workboat, USA.

29. Staten Island Advance (2013) Staten Island Ferry LNG Conversion Planned. Maritime Propulsion.

30. Layton JT, Keller BW (2009) Liquefied Natural Gas: Security and Hazards. Nova Science Publishers Inc, New York. 
31. ABS (2014) Bunkering of Liquefied Natural Gas-fuelled Marine Vessels in North America.

32. Offshore Source (2016) Harvey Gulf Delivers North America's First LNG Marine Fueling Terminal in Port Fourchon, Louisiana.

33. NFPA English Edition (2016) Standard for the Production, Storage, and Handling of Liquefied Natural Gas (LNG). NFPA, USA.

34. Safety4sea (2015) Standards and Guidelines for Natural Gas Fuelled Ship Projects.

35. NFPA 52 (2006) Vehicular Fuel Systems Code. Hamyar Energy Khavarmiyane.
36. Government Publishing Office (2010) 33 CFR Ch. I (7-1-10 Edition) US GPO.

37. Government Publishing Office (2013) PART 127 - Waterfront Facilities Handling Liquefied Natural Gas and Liquefied Hazardous Gas. SCRIBD, USA.

38. United States Department of Labor (2013) Occupational Safety and Health Administration (OSHA). Department of Labor, USA.

39. Blumberg B, Cooper DR, Schindler PS (2005) Business Research Methods.UK. 